\title{
Essential Oils from the Leaves of Three New Zealand Species of Pseudopanax (Araliaceae)
}

\author{
Roderick J. Weston \\ Industrial Research Ltd., P.O. Box 31-310, Lower Hutt, New Zealand. Fax: +64-4-9313-055. \\ E-mail: r.weston@irl.cri.nz
}

Z. Naturforsch. 59c, 39-42 (2004); received July 22, 2003

Essential oils from three of the eleven endemic New Zealand species of Pseudopanax, $P$. arboreus, $P$. discolor and $P$. lessonii, were found to have a fairly uniform composition which was different from that of the oils of Raukaua species that were formerly classified in the Pseudopanax genus. Oils of the three Pseudopanax species all contained significant proportions of viridiflorol and a closely related unidentified hydroazulene alcohol in common. In addition, the oil of $P$. arboreus contained bicyclogermacrene, linalool and long chain hydrocarbons. The oil of $P$. discolor contained nerolidol in abundance $(36.3 \%)$ together with linalool and epi- $\alpha$-muurolol. The oil of $P$. lessonii contained a complex mixture of sesquiterpene alcohols including epi- $\alpha$-muurolol and a mixture of long chain hydrocarbons. Nerolidol and linalool provided the oil of $P$. discolor with a pleasant floral aroma, but the yield of oil was very low $(0.01 \%)$.

Key words: Pseudopanax arboreus, discolor and lessonii, Araliaceae, Essential Oil

\section{Introduction}

The Araliaceae is a family of 65 genera and approximately 800 species, which occur mainly in tropical regions, but some genera are found in areas of temperate climate including New Zealand, where 6 genera are represented. The Meryta, Stilbocarpa and Schefflera genera each have one species in New Zealand, Kirkophytum has 2 species, Raukaua has 3 species and Pseudopanax has 11 species. The taxonomy of the Araliaceae has been revised several times over the past 2 centuries and the New Zealand Pseudopanax species have been placed at some time in the Neopanax, Nothopanax, Panax and Pseudopanax genera (Philipson, 1965; Mitchell and Wagstaff, 1997). More recently, following a study of ribosomal DNA sequences and morphological data, three of these Araliad species were separated from Pseudopanax and reinstated in the genus Raukaua (Mitchell et al., 1997). The essential oils from the leaves of these 3 species were the subject of the previous paper by this author (Weston, 2003). The 11 New Zealand species of Pseudopanax fall roughly into 3 groups, based on morphology. The first group includes those plants which have long narrow serrated coriaceous (leather-like) leaves, typified by $P$. crassifolius, $P$. ferox and $P$. linearis. The second group comprises those species which have similar but much shorter leaves. Two of the species studied in this paper, $P$. lessonii and $P$. discolor, belong to this group and were selected because their leaves, when crushed, emit a weak fragrance. The third group is characterized by its shorter wider fleshier leaves and includes $P$. colensoi, $P$. laetus and $P$. arboreus, the last of which was also included in this study. Little work has been carried out to date on essential oils from Pseudopanax species [see Weston (2003) for a summary of the literature], so the present work was initiated to investigate the yield and composition of the leaf essential oils from 3 New Zealand Pseudopanax species in order to compare the data with those from the closely related Raukaua species previously studied and to add to our scarce knowledge of the oils from Pseudopanax species.

\section{Materials and Methods}

\section{Plant material}

Leaf material was collected in March (late summer - early autumn) from specimens, which were growing in the Otari Native Plant Reserve, Wellington, where documentation for the specimens is held.

\section{Isolation of leaf oil}

The fresh leaves $(150 \mathrm{~g})$ were covered with water (3.5 l), which was boiled for $4 \mathrm{~h}$ and the oil was isolated by hydrodistillation. The distillate was 
extracted with dichloromethane $(3 \times 25 \mathrm{ml})$. The extract was dried over magnesium sulfate and the solvent was removed on a rotary evaporator at $40{ }^{\circ} \mathrm{C}$ and atmospheric pressure.

\section{Analysis of oil composition}

Combined gas chromatography and mass spectrometry was carried out on a Hewlett-Packard (HP) 5890 gas chromatograph coupled to a HP 5970 mass selective detector, using the following conditions: column, Zebron ZB-1 (100\% methylpolysiloxane), $30 \mathrm{~m} \times 0.25 \mathrm{~mm}$ with film thickness $0.25 \mu \mathrm{m}$; carrier gas (He) flow rate of $70 \mathrm{ml} / \mathrm{min}$ was split $70: 1$; injector temperature, $250^{\circ} \mathrm{C}$; transfer line, $280^{\circ} \mathrm{C}$; temperature program, $60^{\circ} \mathrm{C}$ $(1 \mathrm{~min})$, and then $5{ }^{\circ} \mathrm{C} / \mathrm{min}$ to $280^{\circ} \mathrm{C}$. The solvent delay was $2 \mathrm{~min}$ and mass spectrometry was performed at $70 \mathrm{eV}$ and $1.75 \mathrm{scans} / \mathrm{s}$ from $\mathrm{m} / \mathrm{z} 41$ to 500. The oil composition was determined from the mass spectral total ion chromatogram (TIC), which was integrated using the HP Standard ChemStation software, version A.03.00. If the chromatogram obtained by FID was significantly different from that obtained by TIC, then the differences are explained below. Only those components of the leaf oils, which exceeded $0.5 \%$ in abundance, were recorded. Leaf material was taken from only a few specimens, which may not have been truly representative of the species. Components were identified by comparison of their (Kovats) retention indices and mass spectra with those recorded by Adams (2001) and the National Bureau of Standards $75 \mathrm{~K}$ mass spectral library.

\section{Results and Discussion}

\section{Pseudopanax arboreus}

Pseudopanax arboreus (Murray) Philipson (common name, five-finger; Maori name, Whauwhaupaku) is a tree which grows up to 8 metres. It has 5-7 foliate leaves on long $(20 \mathrm{~cm})$ petioles and the serrated obovate leaflets $(5 \mathrm{~cm} \times 15 \mathrm{~cm})$ possess petiolules, $5 \mathrm{~cm}$ long. It grows throughout New Zealand in lowland forests.

The characteristic feature of the oil of the fivefinger was the abundance of bicyclogermacrene (12.9\%; Table I). This product and linalool (5.6\%) were the only significant components of the nonpolar half of the chromatogram of this oil. Viridiflorol $(12.8 \%)$ and an unidentified hydroazulene alcohol (component 26, 10.5\%) both dominated the sesquiterpenoid region of the chromatogram of this oil and in fact, these two compounds were present in the oils of all three species of Pseudopanax which were examined here and were particularly prominent in the oils of this species and $P$. lessonii. Component 39 was prominent in a region of the chromatogram where no other products occurred. Its identity could not be established but it appeared from mass spectral data to be a long chain aldehyde. In the polar region of the chromatogram, two compounds were particularly abundant, namely pentacosane $(14.5 \%)$ and heptacosane $(7.2 \%)$. With the chromatographic conditions used for this work, hydrocarbons constituted nearly $30 \%$ of the oil. Earlier work by Murray and Stanley (1952) indicated that long chain hydrocarbons were abundant components of the essential oils of Pseudopanax species and in the case of the New Zealand species $P$. colensoi were the only components, but it is not possible to determine whether these hydrocarbons had originated from leaf cuticular wax or essential oil glands.

\section{Pseudopanax discolor}

Pseudopanax discolor (Kirk) Harms is a shrub up to 5 metres tall with 3-5 foliate elliptic leaves on petioles $\sim 5 \mathrm{~cm}$ long. The lanceolate serrated leaves are green-bronze in colour. This plant grows in lowland forests, but is found naturally only in the northern half of the north island of New Zealand. Its attractive form and foliage have made it a popular plant in home gardens.

The composition of the oil of $P$. discolor was dominated by the presence of nerolidol, which constituted more than one-third of the entire oil. The next most abundant component was linalool $(7.7 \%)$ and these two components were responsible for the pleasant aroma of the oil. Other significant components, which exceeded $5 \%$ in abundance, were viridiflorol (7.5\%), epi- $\alpha$-muurolol $(5.1 \%)$ and an unidentified hydroazulene alcohol (component 26, 6.5\%).

\section{Pseudopanax lessonii}

Pseudopanax lessonii (DC.) K. Koch (Maori name, Houpara) is a tree up to 6 metres tall. It has $3-5$ foliate leaves on long petioles $(10 \mathrm{~cm})$ and thick obovate serrated leaflets. It grows in coastal forests and scrub and is found naturally in the northern half of the north island of New Zealand. 
Table I. Composition ${ }^{\mathrm{a}}$ (in \%) of the essential oils of the leaves of some Pseudopanax species.

\begin{tabular}{|c|c|c|c|c|c|}
\hline Component & $\mathrm{RT}$ [min] & $\mathrm{KI}^{\mathrm{b}}$ & P. arboreus & P. discolor & P. lessonii \\
\hline 1 Hexanal & 6.1 & 804 & 0.5 & 0.8 & 3.5 \\
\hline 2 Furfural & 6.6 & 835 & - & - & 1.8 \\
\hline 3 Unidentified & 6.9 & 844 & - & - & 0.6 \\
\hline $4(Z)-3-H e x e n o l$ & 7.5 & 861 & - & 1.5 & - \\
\hline 5 Cyclohexanone & 8.3 & 882 & - & 0.5 & 1.4 \\
\hline 6 Octanal & 12.4 & 988 & 0.7 & 0.8 & 1.0 \\
\hline $7 \beta$-Myrcene & 12.5 & 992 & 0.7 & - & - \\
\hline $8(Z)$-3-Hexenyl acetate & 12.7 & 998 & - & 1.0 & - \\
\hline 9 Unidentified & 12.7 & 999 & 0.6 & - & - \\
\hline 10 Unidentified & 13.4 & 1019 & 0.6 & - & 0.7 \\
\hline 11 Cis-(furano)linalool oxide & 15.7 & 1085 & - & 0.6 & - \\
\hline 12 Unidentified & 16.7 & 1090 & - & - & 3.9 \\
\hline 13 Terpinoline & 16.7 & 1092 & 0.7 & - & - \\
\hline 14 Linalool & 16.9 & 1094 & 5.6 & 7.7 & - \\
\hline 15 Unidentified & 19.1 & 1138 & - & - & 0.6 \\
\hline $16 \alpha$-Terpineol & 20.9 & 1179 & 0.6 & 2.5 & - \\
\hline $17 \delta$-Elemene & 28.1 & 1339 & 0.9 & - & - \\
\hline 18 Neryl acetate & 29.2 & 1360 & 0.8 & - & - \\
\hline 19 9-Epi-caryophyllene & 33.2 & 1463 & - & 1.3 & - \\
\hline 20 Bicyclogermacrene & 34.6 & 1499 & 12.9 & 1.5 & 3.0 \\
\hline $21(E)$-Nerolidol & 37.0 & 1560 & 0.8 & 36.3 & 0.8 \\
\hline 22 Unidentified & 37.2 & 1565 & 2.2 & 2.2 & 3.9 \\
\hline 23 Ledol & 37.3 & 1568 & 0.8 & 0.6 & 1.0 \\
\hline 24 Spathulenol & 37.4 & 1570 & 1.0 & 0.9 & - \\
\hline 25 Viridiflorol & 37.8 & 1580 & 12.8 & 7.5 & 19.6 \\
\hline 26 Unidentified & 38.1 & 1587 & 10.5 & 6.5 & 7.0 \\
\hline 27 Unidentified & 38.1 & 1588 & - & - & 11.7 \\
\hline 28 5-Epi-7-ері- $\alpha$-eudesmol & 38.5 & 1605 & 3.8 & 3.0 & 2.5 \\
\hline 29 Unidentified & 38.6 & 1607 & - & - & 2.7 \\
\hline 30 Unidentified & 39.2 & 1612 & 1.4 & 1.3 & 2.5 \\
\hline 31 Unidentified & 39.4 & 1614 & - & - & 2.7 \\
\hline $32 \beta$-Atlantol & 39.6 & 1616 & - & 0.6 & - \\
\hline 33 Unidentified & 39.8 & 1630 & - & - & 2.8 \\
\hline 34 Epi- $\alpha$-cadinol & 39.8 & 1631 & - & 3.3 & - \\
\hline 35 Unidentified & 39.9 & 1634 & - & - & 0.6 \\
\hline 36 Unidentified & 39.9 & 1635 & - & - & 2.5 \\
\hline 37 Epi- $\alpha$-muurolol & 40.2 & 1643 & - & 5.1 & 5.8 \\
\hline 38 Benzyl salicylate & 47.0 & 1865 & - & 0.5 & - \\
\hline 39 Long chain aldehyde & 47.3 & 1874 & 3.2 & - & - \\
\hline 40 Tricosane & 61.3 & 2302 & 1.6 & 0.7 & 1.5 \\
\hline 41 Hydrocarbon & 62.6 & 2353 & 2.1 & 3.6 & 1.9 \\
\hline 42 Hydrocarbon & 62.6 & 2354 & 2.2 & 2.4 & 1.1 \\
\hline 43 Hydrocarbon & 62.7 & 2356 & - & - & 1.7 \\
\hline 44 Tetracosane & 63.8 & 2402 & 1.0 & - & - \\
\hline 45 Unidentified & 64.0 & 2410 & 0.7 & - & - \\
\hline 46 Pentacosane & 66.6 & 2500 & 14.5 & 0.9 & 1.8 \\
\hline 47 Unidentified & 69.7 & 2627 & - & - & 0.6 \\
\hline 48 Heptacosane & 71.5 & 2698 & 7.2 & 1.7 & 2.0 \\
\hline 49 Unidentified & 73.2 & 2768 & - & - & 1.5 \\
\hline Oil yield [g/kg fresh leaves] & & & 0.04 & 0.1 & 0.2 \\
\hline
\end{tabular}

a Determined by integration of the GC-MS total ion chromatogram $(\geq 0.5 \%)$.

${ }^{\mathrm{b}}$ Kovats Index.

Unlike the oils of the previous two species, that of $P$. lessonii contained no linalool and indeed contained no detectable monoterpenes and the weak aroma of this oil was due to the "leafy" compo- nents 1-6, all of which have "green" aromas. A feature of the composition of the oil of $P$. lessonii was the large number of components which were not identified with certainty, despite the extensive 
compilation of spectra in the National Bureau of Standards $75 \mathrm{~K}$ mass spectral library and that of Adams (2001). This was due to the complexity of the chromatogram and the unsatisfactory resolution which resulted from the large number of components particularly in the $1500-1650$ region where the sesquiterpene alcohols occur. Abundant components of this oil included viridiflorol (19.6\%) and two closely related hydroazulene alcohols, which were effectively coincident in the chromatogram (total 18.7\%), together with a number of other unidentified sesquiterpene alcohols. Like the oil from the previous species, that of $P$. lessonii contained a notable level of epi- $\alpha-$ muurolol $(5.8 \%)$ and a range of long chain hydrocarbons.

\section{Oil aroma}

Of the three oils examined in this work, that of $P$. discolor had a strong pleasant fresh green floral aroma which will have been due largely to the presence of linalool $(7.7 \%)$ that is the quintessential component of floral aromas and nerolidol $(36.3 \%)$, which has a fresh floral odour resembling that of rose, lily and apple (Fenaroli, 1975) and orange flowers (Poucher, 1974). None of the three species studied here afforded an essential oil in

Adams R. P. (2001), Identification of Essential Oil Components by Gas Chromatography/Quadrupole Mass Spectroscopy. Allured Publ. Corp., Carol Stream, Illinois.

Fenaroli G. (1975), Fenaroli's Handbook of Flavor Ingredients, $2^{\text {nd }}$ ed., vol. 2, (Furia T. E. and Bellanca N., eds.). CRC, Ohio, p. 426.

Mitchell A. D. and Wagstaff S. J. (1997), Phylogenetic relationships of Pseudopanax species (Araliaceae) inferred from parsimony analysis of rDNA sequence data and morphology. Pl. Syst. Evol. 208, 121-138.

Mitchell A. D., Frodin D. G., and Heads M. J. (1997), Reinstatement of Raukaua, a genus of the Araliaceae centred in New Zealand. N. Z. J. Botany 35, 309-315. sufficient yield that would attract commercial interest.

\section{Taxonomy}

The work of Mitchell and Wagstaff (1997) showed that the 3 species studied here have a close evolutionary relationship to one another and to the other New Zealand Pseudopanax species, but are well separated from the Raukaua species, oils of which were studied in the preceding paper. If anything, $P$. arboreus is separated to a small degree from $P$. discolor and $P$. lessonii in terms of evolution, but such a distinction is not obvious from the essential oil composition. Two compounds, viridiflorol and a closely related hydroazulene alcohol were major components of and common to the oils of all three species studied here. The chromatograms and composition of these oils displayed a degree of uniformity which was reflected in the genetic and morphological analyses of Mitchell and Wagstaff (1997), but which was different from those of the Raukaua species studied earlier (Weston, 2003), species which were formerly classified in the Pseudopanax genus. The composition of the essential oils of these species therefore was consistent with the separation of these genera.

Murray J. and Stanley B. G. (1952), The essential oil of Nothopanax simplex. J. Appl. Chem., 5-7.

Philipson W. R. (1965), The New Zealand genera of the Araliaceae. N. Z. J. Botany 3, 333-341.

Poucher W. A. (1974), Perfumes, Cosmetics and Soaps, $7^{\text {th }}$ ed., vol. 1, (revised by Howard G.). Chapman and Hall, London, p. 273.

Weston R. J. (2004), Essential oils of the leaves of the Raukaua genus (Araliaceae). Z. Naturforsch. 59c, $35-38$. 